\title{
MIXED AND HYBRID SYSTEMS OF JUSTICE AND THE DEVELOPMENT OF THE ADVERSARIAL PARADIGM: EUROPEAN LAW, INQUISITORIAL PROCESSES AND THE DEVELOPMENT OF COMMUNITY JUSTICE IN THE COMMON LAW STATES
}

TYRONE KIRCHENGAST"

\begin{abstract}
This article considers the movement away from traditional adversarial processes in common law jurisdictions by considering the influence of civil European law and procedure on the development of adversarial justice. It does this by first considering aspects of adversarial procedure that preclude alternative approaches to justice against the Framework Directives of the Council of Europe, the jurisprudence of the European Court of Justice and the European Court of Human Rights, and the practice and procedure of the International Criminal Court. Collectively, these European approaches demonstrate how mixed and hybrid adversarial-inquisitorial systems address the needs of trial participants in a participatory model of justice. The second part of this article considers the growth in interventionist problem-solving and community-based justice across four common law jurisdictions that traditionally identify as adversarial, namely the United States, Canada, England and Wales, and Australia. The rise of interventionist community courts in adversarial jurisdictions demonstrate that movement toward mixed and hybrid processes akin to the civil European experience is neither radical nor alternative, but rather supported by a line of domestic authority that for some time has recognised the benefits of alternative, inquisitorial and court supervised systems of justice.
\end{abstract}

KEYWORDS: Adversarial Justice. Adversarial Procedure. European Law. Common Law.

\section{INTRODUCTION}

Adversarial justice is known by its dependence on counsel-led examination of witnesses, the testing of evidence by cross-examination, before an independent magistrate or judge. The prosecution too is removed from the functioning of the court, and take their place at the bar table from which they make submissions as independent counsel. However, the modern adversarial criminal trial is more than the popularly conceived notion of the trial before independent judge and jury. The traditional adversative criminal trial is being increasingly circumvented for alternative pathways to justice, such as summary or restorative justice. Arguably, the modern adversarial criminal trial functions as a transformative site open to alternative practises and processes to meet the needs of a range of justice stakeholders. This article explores the notion that the adversarial criminal trial

Associate Professor, University of Sydney Law School. NSW 2006, Australia. A version of this paper was presented in August 2017 as Visiting Professor, Faculty of Law, Universidade Federal de Minas Gerais, Brazil (supported at that time by UNSW Law). This article has been developed out of work first presented in Victims and the Criminal Trial, Palgrave Macmillan 2016, and The Criminal Trial in Law and Discourse, Palgrave Macmillan 2010.

Email: tyrone.kirchengast@sydney.edu.au. 
is an inclusive institution that, consistent with its history, continues to change to meet new social needs. ${ }^{1}$ This article follows the argument that the adversarial criminal trial is increasingly open to inquisitorial practice and procedure, as seen in the continental European civil law approach, and that this is particularly seen toward the lower end of local court or magistrates' justice. States founded on the adversarial method of engagement increasingly embrace a participatory model of mixed and hybrid justice that seeks to protect vulnerable participants, including the accused and victim, to provide court-led intervention and treatment that sees the prosecution, defence and court work together utilising an inquisitorial method of justice.

The modern adversarial criminal trial has responded to the rise of an international human rights movement, a law and order politics, terrorism, the rise of victims' rights, and a movement toward therapeutic and problem-solving justice. ${ }^{2}$ As such, debate has shifted toward the extent to which adversarial justice is transgressive, as not bound to one particular and exclusive way of doing justice, but open to new processes that allow courts to take on new roles as protecting the needs and interests of trial participants. The common law states of the United States, Canada England and Wales, and Australia, once protective of their standing as states whose legal systems are founded on adversarial engagement to the exclusion of all other approaches, now look to European civil process and the international courts as as way of extending their domestic legal processes in new ways. ${ }^{3}$ Each legal system has moved beyond the rhetoric of an insistence on strict adversarial engagement to embrace alternative forms of court-based justice, including community justice, that follows methods of engagement similar to inquisitorial courts of justice. The Framework Directives of the Council of Europe, the jurisprudence of the European Court of Justice and the European Court of Human Rights, and the practice and procedure of the International Criminal Court, encourage the development of local, domestic practises that fuse aspects of adversarial and inquisitorial procedure into a mixed and hybrid model of justice. While this has a direct impact across member states and in Europe, the human rights jurisprudence which the European courts support has an impact on more divergent states, including United States, Canada England and Wales, and Australia. Indeed, examination of local authorities indicates that these common law states have been open to alternative processes beyond counsel-led, adversarial justice for some time. ${ }^{4}$

1 See Kirchengast, T. (2010) The Criminal Trial in Law and Discourse, Palgrave Macmillan.

2 Duff, A., Lindsay, F., Marshall, S., and Tadros, V. (2007) The Trial on Trial Volume 3: Towards a Normative Theory of the Criminal Trial, Hart Publishing: Oxford.

3 See generally Victorian Law Reform Commission (2016) Victims of Crime in the Criminal Trial Process, Final Report, September 2016.

$4 \quad$ See discussion of $R v$ Cook [1997] 1 SCR 1113, $R v$ Camberwell Green Youth Court [2005] 
The adversarial criminal trial is held out as the main model by which accusations of wrongdoing are heard and determined in common law jurisdictions. There is divided opinion as to the extent to which the adversarial trial may be adapted and developed toward an inquisitorial, court-led model. ${ }^{5}$ This debate is characterised by diverse opinions which range from the safeguarding of the adversarial trial as the only means by which defendant rights will be successfully protected against abuses of state power, such as charges brought on the weakest of evidence, police misconduct, false accusations or political imperative. Others suggest that the scope of the adversarial trial, as an exclusive contest between police, prosecution and defendant, and as presided over by an independent magistrate or judge, represents a model of justice that is in decline, or at least requires rethinking. ${ }^{6}$ Such perspectives suggest that the trial and adversarial model more generally ought to be construed in terms of those procedures significant to the functions of justice - the requirement of a 'fair trial' that seeks to balance the competing needs of witnesses, victims, defendants, the community, and state. ${ }^{7}$ Various common law jurisdictions have now moved away from the strict requirements of the adversarial trial to other innovative or nuanced modes of determining liability for wrongdoing, or in meting out punishment following conviction.

A movement toward therapeutic courts such as community courts, or modes of sentencing that include the victim, police, accused, and community, such as the community courts traced in this article, provide new ways of doing justice that significantly modify traditional adversarial processes. The broader inclusion of victims in trials, by way of human rights decisions that protect the rights of vulnerable rape or child victims, or in sentencing, by way of victim impact or personal statements, has attracted criticism from those advocating that trials only proceed as a contest between an independent prosecution and defence. ${ }^{8}$ Those advocating such approaches suggest that the traditional scope of

1 All ER 999, Gately $v$ The Queen (2007) 232 CLR 208, and Crawford $v$ Washington (2004) 541 US 36 toward the end of this article.

5 Wolhunter, L., Olley, N. and Denham, D. (2009) Victimology: Victimisation and Victims' Rights, Routledge Cavendish: Oxon., p. 173; Duff, A., Lindsay, F., Marshall, S., and Tadros, V. (2007) The Trial on Trial Volume 3: Towards a Normative Theory of the Criminal Trial, Hart Publishing: Oxford.

6 See Schwikkard, PJ. (2007) 'Convergence, Appropriate Fit and Values in Criminal Process' in Roberts, P. and Redmayne, M. (eds.), Innovations in Evidence and Proof: Integrating Theory, Research and Teaching, Hart Publishing: Oxford, pp. 331-346; Schwikkard, PJ. (2008) Possibilities of Convergence: An Outside Perspective on the Convergence of Criminal Procedures in Europe, Kluwer; Summers, S. (2007) Fair Trials: The European Procedural Tradition and the European Court of Human Rights, Hart Publishing: Oxford.

7 Nonet, P. and Selznick, P. (1978) Law and Society in Transition: Toward Responsive Law, Transaction Publishers: London; Simon, WH. (1978) 'Ideology of Advocacy: Procedural Justice and Professional Ethics', Wisconsin Law Review, 31, 1, 29-144.

8 Sebba, L. (2009) 'Victim-Driven Criminalisation' in McSherry, B., Norrie, A. and Bronitt, S. 
the adversarial trial is under attack from a punitive law and order ideology, such that the key functions of the trial ought to be reaffirmed to countenance the new or innovative developments of law and justice that are manifestly identified as detracting from the rights of the accused. ${ }^{9}$ Alternatively, such perspectives also realise the potential for change, principally within the confines of the adversarial tradition, which may be extended to include inquisitorial or other approaches without unacceptably detracting from the core functions of adversarial justice. The European courts have been a central influence here.

There is now less of a generally agreed model as to the adversative criminal trial, with a movement to court-based processes that see new working arrangements between traditionally independent trial participants. However, the movement away from adversarial justice has spawned a counter movement for the concerted re-assertion of the bounds of the adversative model, mainly through the rejection of principles of inquisitorial justice. Such a counter argument remains problematic, given that the adversarial trial never took a specific form, and that comparative law tells of the significant overlap between adversarial and inquisitorial models. The point remains, however, that the adversarial criminal trial is neither normative nor prescriptive but discursive and decentralised, and the guiding role of European law and justice in developing the human rights frameworks of common law states suggests, particularly at the lower end of summary and community justice, indicates that this trend is increasingly characterises the preferred practise and procedure of criminal courts in common law states.

\section{ADVERSARIAL JUSTICE AND TRIAL FAIRNESS}

Justice Deane in Dietrich v The Queen (1992) 177 CLR 292, identifies the modern criminal trial as one that is characterised as an adversarial, accusatorial tribunal, before an independent magistrate or judge:

A criminal trial in this country is essentially an adversarial process. Where the charge is of a serious crime, the prosecution will ordinarily be in the hands of counsel with knowledge and experience of the criminal law and its administration. The substantive criminal law and the rules of procedure and evidence governing the conduct of a criminal trial are, from the viewpoint of an ordinary accused, complicated and obscure. While the prosecution has a duty to act fairly and part of the function of a presiding judge is to seek to ensure that a criminal trial is fair, neither prosecutor nor judge can or should provide the advice, guidance and representation which an accused must ordinarily have if his case is to be properly presented. Thus, it is no part of the function of a prosecutor or trial judge to advise an accused before the commencement of a trial about the legal issues which might arise on the trial, about what evidence

(eds.) Regulating Deviance: The Redirection of Criminalisation and the Futures of Criminal Law, Hart Publishing: Oxford, pp 65.

9 Above, n 6. 
will or will not be admissible in relation to them, about what inquiries should be made to ascertain what evidence is available, about what available evidence should be called, about possible defences, about the possible consequences of cross-examination, about the desirability or otherwise of giving sworn evidence or about any of a multitude of other questions which counsel appearing for an accused must consider and in respect of which such counsel must advise in the course of the preparation of a criminal trial. Nor is it consistent with the function of prosecutor or trial judge to conduct, or advise on the conduct of, the case for the defence at the trial. Nor, in the ordinary case, is an accused capable of presenting his own case to the jury as effectively as can a trained lawyer. ${ }^{10}$

The adversarial criminal trial is held as a discrete part of the criminal process through which accusation is made, counsel appointed, and guilt determined, usually by jury, as instructed by independent magistrate, or in rare cases, a judge sitting alone. The trial is therefore seen to constituted by a prescribed set of pre and post-trial processes that determine the means by which defendants are held to account for their wrongdoing. The independence of parties and of the judge in particular is key. Adversarial justice is not court-led. Judges and courts cannot recommend that charges be brought, and cannot insist that alternative charges be laid in light of a plea-deal agreed between prosecution and accused. ${ }^{11}$ The police or prosecution determines the charges, acting alone. ${ }^{12}$ Judges are generally unable to call witnesses and cannot question those that are called by the parties. While the policing of the initial incident, arrest, charge, committal, arraignment, and then sentencing and punishment of the accused are indeed separate from the trial in a procedural sense, they are closely connected to the trial in a substantive sense, and constitute the notion of the 'fair trial' upon which adversarial justice is founded. ${ }^{13}$ While the separation of the trial is supported by doctrinal approaches that constitute the trial as a discrete mode of inquiry concerned with establishing guilt beyond reasonable doubt, the discourses that comes to bear on the trial, both its substantive character and the form it takes, are very much common to the broader functioning of the criminal justice system, which relies on a prescribed notion of what it means to be put on trial. Recourse to due process and procedural fairness before an independent judge and court, acting on a charge determined by a prosecution independent of the

10 Dietrich $v$ The Queen (1992) 177 CLR 292, p. 334-335.

11 In certain states in the US, for instance, plea-deals must be approved by the court. In NSW, Australia, plea-deals may only be accepted where the court is furnished with a certificate evidencing that the victim has been previously consulted regarding a charge negotiation (see s 35A Crimes (Sentencing Procedure) Act 1999 NSW). Despite some limitation on the acceptance of plea-deals, however, the court never attains the power to determine the charge and prosecution of the accused. This power always remains with the executive.

12 Although in practice police determine the initial charge, and the prosecution to indictment that proceeds to jury trial. See $R v$ Andrew Foster Brown (1989) 17 NSWLR 472; GAS $v$ The Queen, SJK $v$ The Queen (2004) 217 CLR 198.

13 Barton $v$ The Queen (1980) 147 CLR 75. 
state, is thus wholly constitutive to the notion of a 'fair trial' in an adversarial context. Independence of participants substantially supports the integrity of justice in popular conscience in common law countries. ${ }^{14}$

Adversarial criminal trials are also constituted through processes that define the way evidence is led and tested in court. For the most part, adversarial justice is defined as a discrete, forensic process, solely concerned with establishing the truth of a criminal accusation. However, the focus on the adversarial trial as a 'truth finding' institution has long been criticised given the way evidence is adduced strategically to accord with a particular version of events, and distorted in terms of the case counsel make for their client. This is what Langbein terms the 'combat effect' of the adversarial criminal trial. ${ }^{15}$ This criticism notwithstanding, the adversarial criminal trial remains an important means by which criminal liability for wrongdoing may be determined. What is less clear is whether the classical notional of adversative justice ought to preclude alternative ways of doing justice, particularly where the adversarial trial fails to protect the interests of at-risk individuals and groups, including the accused, victims and member of the community.

\section{DEVELOPING ADVERSARIAL JUSTICE: LESSONS FROM CONTINENTAL EUROPE}

Notable examples of the departure from the adversarial model arise under the Directive of the European Parliament and of the Council, (2012) 2012/29/ EU, 25 October 2012 establishing minimum standards on the rights, support and protection of victims of crime, and replacing Council Framework Decision [2012] 2001/220/JH, of the Council of Europe, binding on member states. All European countries, except for Germany and France, adopt adversarial principles within their inquisitorial approach, by allowing counsel-led evidence and crossexamination at trial. ${ }^{16}$ Such Framework Directives, then, have the capacity to challenge and develop adversarial approaches where there is a need to attend to the welfare of the victim during the trial. It specifically applied to at-risk, vulnerable and child victims and witnesses. Framework Directives do not have a direct effect on the domestic laws of member state, but form part of community law which, under the principle of harmonious interpretation, obliges national courts to interpret domestic law in conformity with community law. ${ }^{17}$ Such Directives do

14 See generally, Woolmington $v$ DPP [1935] AC 462.

15 Langbein, JH. (2003) The Origins of the Adversary Criminal Trial, Oxford University Press, Oxford, pp. 103-105.

16 Lorenzmeier, S. (2006) 'The Legal Effect of Framework Decisions - A Case-Note on the Pupino Decision of the European Court of Justice', Zeitschrift für Internationale Strafrechtsdogmatik, 12, pp. 583-588.

17 Albeit movement to Framework Directives from Framework Decisions was designed to limit discretionary ratification and enforcement by member states. See art. 82(2) of the Treaty on the 
not have a direct effect but may give direction to the overall result to be achieved, rather than the processes for achieving such results. The interpretation of such laws, moreover, must be consistent with the defendant's right to a fair trial. The Framework Directive of 2012, therefore, provides victims with several important rights that encourage the integration of inquisitorial procedures on the domestic level of member states. These include rights ordinarily reserved for inquisitorial systems where victims retain the right to accessory and adhesive prosecution. Rights include access to information (arts. 4, 5 and 6), to interpretation and translation (art. 7), to review a decision not to prosecute (art. 11), to restorative justice (art. 12), to legal aid (art. 13), to compensation (art. 16), to privacy (art. 21), and to protections during proceedings (arts. 23 and 24).

These departures for the protection of the victim and the maintenance of a participatory model of justice that includes the victim pursuant to inquisitorial practice not otherwise known to adversarial process is enforceable within member states, however, to the extent recognised by the European Court of Justice in Criminal Proceedings Against Pupino [2005] 3 WLR 1102. Pupino concerns a series of charges brought against a nursery school teacher in Italy for allegedly committing several offences involving the misuse of discipline against students aged less than five years of age. The offences were punishable under the Italian Code of Criminal Procedure, which under art. 392 also provided measures for the use of evidence gathered at the preliminary enquiry for use at trial, in order to protect vulnerable victims aged less than sixteen years. Article 392, however, was limited to strictly enumerated sexual offences. Article 398 additionally allowed for the taking of evidence by special arrangement so as to protect the dignity and character of vulnerable witnesses. Pupino opposed the application, arguing that such provisions were not contained in art. 392. In Pupino, the ECJ ruled that art. 35 of the Treaty on European Union gives the ECJ the power to give preliminary rulings on Framework Decisions, including the measures used to implement them. Pupino rules that individuals may apply the Framework Decision of 2001 (replaced by the Framework Directive of 2012) to seek a conforming opinion of national law. The dual effect of harmonious interpretation and the rights of individuals to invoke the Framework Decision in national courts allows for the enforcement of victim rights on a domestic basis. Victims may rely on the Framework Decision to the extent, however, that a member state or national court is willing to give it indirect effect in their interpretation of domestic law.

Although not confined to common law jurisdictions, Pupino demonstrates how trial processes that are adversarial in nature, particularly those procedures that seek to challenge the prosecution evidence, may be modified to allow for the protection of vulnerable parties. Similar approaches are adopted throughout 
the common law world, with regard to special provisions for the examination and cross-examination of rape victims, or other vulnerable classes of victim, such as children.

The Convention for the Protection of Human Rights and Fundamental Freedoms, otherwise known as the European Convention on Human Rights ('ECHR'), also presents a challenge to nominal adversarial processes. The ECHR has been used to challenge domestic processes for the protection of vulnerable victims, such as child victims or witnesses or victims of sexual assault or rape. Under the ECHR, such victims deserve certain protections and rights to privacy during the course of the trial. It is well known that vulnerable victims will often endure additional trauma by being called as a witness to testify in court in order to secure a conviction against their alleged offender. Articles 6 and 8 of the ECHR provide rights to a fair trial and rights to privacy respectively. Both articles have been interpreted by the European Court of Human Rights ('ECtHR') in the context of the extent to which each article provides certain protections for victims of crime called to participate in the trial process. The ECtHR takes the view that, when a victim or witness may be too afraid to testify, that their rights and interests may legitimate the use of anonymous evidence, hearsay evidence, or special measures, including using pre-recorded interviews. Demski $v$ Poland (2008) 22695/03, for example, stands as an example of the extent to which the ECtHR will go towards balancing the interests of the victim against those of the defendant in a participatory and proportionate model of justice:

The Court reiterates its case-law regarding rape cases in that there exist requirements inherent in the States' positive obligations to establish and apply effectively a criminal-law system punishing all forms of rape and sexual abuse (M.C., cited above, $\mathbb{1} 185$ ). The Court acknowledges that the special features of criminal proceedings concerning rape might require balancing the needs of the defence against those of witnesses or victims called upon to testify. Such proceedings are often conceived of as an ordeal by the victim, in particular as they entail being confronted again with the defendant. However, in the light of the findings above, in the present case it cannot be said that the witness's whereabouts were unknown or that she sought ways to avoid a confrontation with the defendants (see Scheper $v$ the Netherlands (dec), 39209/02, 5 April 2005). Had the domestic court made more effort to summon the witness to the proceedings and had she demonstrated that her participation would have had an adverse effect on her mental state, the applicant's complaint that his defence rights had not been respected would have been put in a different perspective. The Court further observes that arrangements could in any event have been made to allow M.H. to give evidence in a manner which spared her the ordeal of an adversarial procedure while respecting the rights of the defence (see W.S. v. Poland, no. 21508/02, $\$ 57,19$ June 2007 and S.N., cited above, $\mathbb{S} 47$ ).

The case of Criminal Proceedings Against Pupino [2005] 3 WLR 1102 indicates how the victim of crime has been increasingly integrated into trial processes on an international basis. Several decisions of the ECtHR are seminal 
in further demonstrating the impact of the victim of crime on the shaping of a modified trial process that challenges the traditional boundaries or 'exclusivities' of the adversarial criminal trial. Several aspects of traditional adversarialism have been challenged by virtue of the integration of victim rights under art. 6 and 8 of the ECHR. The areas that demonstrate this challenge to conventional proceedings include the admission of anonymous witness evidence, hearsay or out of court statements, the use of pre-recorded testimony, and a victim's right to privacy both in their personal lives, and at trial. Although art. 6 does not refer to the victim, the ECtHR has nonetheless incorporated the victim in terms of the proportionality requirement of the defendant's right to a fair criminal trial. Victims have been accorded an independent right to a fair civil hearing under art. 6 as well.

The extent to which witnesses able appear anonymously was at issue in Doorson $v$ The Netherlands (1996) 22 EHRR 330. In Doorson, a drug trafficking case, witnesses had been granted anonymity out of fear of reprisals from the defendant. Although victims' rights are not expressly covered by art. 6 , other rights that concern the victim, such as those that protect the life, liberty and security of the person (art. 5), and respect for private and family life (art. 8), are included in the ECHR. As such it is for the court to balance the interests of defendants to know their accuser and/or the individuals providing evidence against them, in appropriate cases, with the personal interests of those witnesses. Proving testimony anonymously can therefore be used to ensure that the key witnesses are protected while allowing the defence to test their evidence in a way that maintains that anonymity. It is for the court to ensure a fair process is implemented that gives the defendant access to the prosecution witnesses without compromising the anonymity of the witnesses.

As a result, anonymous witness statements may be used in relevant cases where the victim or witness is scared of testifying in open court. PS $v$ Germany (2003) 36 EHRR 61, a case involving a child victim of sexual assault, held that art. 6 requires that the interests of young witnesses be sufficiently protected, albeit in this matter, as the witness statement was the only direct evidence against the accused, the court ruled that art. 6(3)(d) had still been violated. In SN $v$ Sweden (2004) 39 EHRR 13 a victim of sexual assault gave evidence via video recording, forming almost the sole evidence upon which the defendant was convicted. The ECtHR held that, out of recognition of the vulnerability of sexual assault victims, and the realisation that the trial is likely to cause further trauma, a victim's right to their private life must be considered in determining whether the defendant indeed received a fair trial. However, any special arrangements adopted to help protect the victim mist not stop the defendant from being able to contest the evidence. The ECtHR ruled that art. 6(3)(d) had not been violated due to the 
defendant's counsel consenting to the victim being interviewed by police without the defendant present. ${ }^{18}$

The model adopted by the ICC provides for the incorporation of both adversarial and inquisitorial approaches. The ICC contains a pre-trial examining or investigative division, similar to the examining magistrate that works alongside the police and the prosecution to review the material relevant to the charge in domestic inquisitorial jurisdictions. Knoops suggests that the hybrid approach is key to the functions of the ICC, thus:

A significant aspect of the ICC Statute is that, during its drafting stage, delegates made a conscious effort to negotiate a statute and set of RPE [rules of procedure and evidence] that were acceptable to all. One could say that the battle between common law and civil law was there replaced by an agreement on common principles and civil behaviour. It can therefore be said that the ICC Statute and RPE represent a truly international set of procedures, acceptable to the major legal systems of the world and drawing on the experiences of the ICTY [International Criminal Tribunal for the former Yugoslavia] and ICTR [International Criminal Tribunal for Rwanda]. Some novel procedures were created with predominantly civil law features, these being:

- admissibility of evidence and defences;

- pre-trial proceedings;

- supervisory responsibility of the ICC over arrested individuals; and

- rights of victims and witnesses. ${ }^{19}$

Reflecting on the European tradition of auxiliary prosecutions, Sanders argues that a process that allows for the participation of both victim and defendants increases the opportunity for dialogue and understanding. ${ }^{20}$ This reduces secondary victimisation by being excluded from the criminal justice system altogether, or by being called to participate against the will of the witness.

The varying perspectives on the scope and form of the criminal trial considered in this section suggests that the combination of the traditions of European civil law within new human rights frameworks allows for the dynamic modification of the adversarial trial process for the inclusion of inquisitorial processes. As such, a persuasive case is made for the modification of the criminal trial to a less adversative form, in order to achieve its goal of determining liability for wrongdoing in circumstances where the adversarial process will likely exclude participants and in so doing, compromise evidence. On this point, Dworkin reminds us that on a principled basis, law should not merely advocate consensus

18 Ellison, L. (2002) The Adversarial Process and the Vulnerable Witness, Oxford University Press: Oxford., pp. 67, 78, 154.

19 Knoops, GJ. (2007) Theory and Practice of International and Internationalized Criminal Proceedings, Kluwer Law International: The Netherlands., p. 8.

20 Sanders, A. (2002) 'Victim Participation in an Exclusionary Criminal Justice System' in Hoyle C. and Young R. (eds.) New Visions of Crime Control, Hart Publishing: Oxford, pp. 197-222. 
or be seen as a vehicle of politics. ${ }^{21}$ For Dworkin, law should act to restrain politics to ensure that the political community acts in an ordered, coherent and principled way, with regard to all members of society. It is not a simple matter of arguing, then, that the trial is to take whatever form expedient to a given moment of people, politics or community expectation. Rather, in order to be true to the essential characteristics of the trial as it has emerged over the centuries, we must be critical of those normative perspectives that proscribes the form and function of the trial as an a priori product of adversarial justice to the exclusion of alternative ways of doing justice. ${ }^{22}$ By examining the character of the trial as a vehicle of inclusion, the trial can be developed in principle to include the mixed and hybrid processes of adversarial and inquisitorial justice that characterise the European civil law tradition, as an institution that holds wrongdoers to account against the needs various stakeholders of law and justice, including the victim and community. The approach that characterises the present European models of justice provide that the criminal trial ought not be prescribed by nationalistic interest, but rather be open to development to accommodate reforms that borrow from different legal traditions to realise the interests of different groups. It should do this to maintain the criminal trial as an institution of control and inclusion that provides for participatory justice. ${ }^{23}$ Furthermore, it means that voices and perspectives are not necessarily silenced out of the need to maintain a normative, prescribed adversative process that speaks for some and not others.

\section{THE PROGRESSIVE QUALITIES OF MIXED AND HYBRID SYSTEMS: DEVELOPING ADVERSARIAL JUSTICE THROUGH COURT INTERVENTION}

The jury trial is situated as the centrepiece of adversarial criminal justice despite its limited use as a tribunal of fact. The influence of law reform initiatives on processes that constitute the trial evidence how the adversarial trial is responsive to change, and how this has been a characteristic of the trial since it emerged out of rituals of customary justice. ${ }^{24}$ Furthermore, the modern influences on the form and function of the trial, namely those asserted by the victim of crime, defendant, the community, and the state, evidence how the criminal trial is more appropriately recognised as a repository of disciplinary power that includes voices and perspectives. Processes of law reform increasingly recognise the need

21 Dworkin, R. (1986) Law's Empire, Harvard University Press: Cambridge, Massachusetts.

22 As to the range of normative and nationalistic assumptions in the work of the ECtHR, see Summers, S. (2007) Fair Trials: The European Procedural Tradition and the European Court of Human Rights, Hart Publishing: Oxford., pp. 3-10.

23 See discussion in the last section on the significance of the accusatorial trinity and equality of arms arguments.

24 Unger, R. (1976) Law in Modern Society: Toward a Criticism of Social Theory, Free Press: New York. 
to modify adversarial procedure to better accommodate the needs of different groups, to allow for more efficient and fairer prosecution and punishment, in the interests of inclusive justice. ${ }^{25}$ The influence of the European models of justice that embrace the benefits of an inquisitorial procedure evidence how different ways of doing justice, by reaching different communities in a participatory model of court-led justice, may inspire change in the common law courts. The dominance and normative positioning of the adversarial criminal trial is reconsidered as a matter of course.

This section examines the rhetoric of the adversarial criminal trial from a number of perspectives, from the dynamics of justice in the local or magistrates' court, and through the emergence of therapeutic jurisprudence and problemsolving justice and ultimately, the establishing of courts of community justice in the US, Canada, England and Wales and Australia, that substantially embrace an interventionalist model of justice already known to inquisitorial procedure.

\section{SUMMARY JUSTICE}

The rhetoric of the trial as the centrepiece of the criminal law is most ably demonstrated by the fact that today few defendants actually proceed to trial by judge and jury. In most common law jurisdictions, processes have been established to guide the defendant from trial by judge and jury for summary proceedings before a magistrate sitting alone. Certainly, in Australian courts, such as those in New South Wales, a clear majority of charges are dealt with by the local court constituted by a magistrate sitting alone. Around 97 per cent of charges are finalised before a magistrate. ${ }^{26}$ Similar statistics can be found throughout the common law world, where trial by judge and jury now sits as the 'exemplar' of justice, the rhetoric of which grants defendants a full-measure of procedural fairness, including committal for trial on the basis of the review of evidence or alternatively by grand jury process, arraignment of the indictment, state funded counsel for serious offences, a jury of twelve laypersons, and an independent judge of senior rank. On the other hand, the local courts adopt a summary process, characterised as an institution of technocratic justice, where defendants are offered limited due process to process defendants quickly and efficiently. ${ }^{27}$ Most matters end by way of guilty plea, despite some accused being able to mount a defence against the charge that might well see them acquitted. McBarent indicates why expediency characterises local court justice:

25 Above, $\mathrm{n} 4$.

26 Including matters finalised in the Local Court and Children's' Court. See BOCSAR (2016) Criminal Court Statistics 2016, NSW Government, http://www.bocsar.nsw.gov.au/Pages/ bocsar_court_stats/bocsar_court_stats.aspx.

27 McBarnet, D. (1981) Conviction: Law, the State and the Construction of Justice, Palgrave Macmillan: UK, pp. 143-149; as to the history of summary justice, see McBarnet, D. (1981) 'Magistrates' Courts and the Ideology of Justice', British Journal of Law and Society, 8, 2, 190. 
Adversarial trial processes are substantially modified in the lower courts as unnecessary on two grounds: first, both the offences and the penalties are too trivial; second, the issues and processes are such that the niceties of law and lawyers are irrelevant. ${ }^{28}$

Although jurists hold that the trial sets the standard by which we measure rules of due process that, to varying extents, are available in the summary courts, the reality is that the criminal process for most defendants and other participants exists outside any notion of the criminal trial experience as it is captured in the common rhetoric of criminal law and justice. This adds to the weight of evidence suggesting that criminal law is largely shaped by doctrines of knowledge that assume the significance of the trial throughout the criminal law. Rather than shaping the whole of the criminal law, however, the trial is today only one element of a highly evolved institution of justice that includes a variety of means to justice. In the local court perspective, this includes new and innovative processes that call for the participation of agents of justice, including victims of crime and members of the community, who would otherwise be excluded if the ideological 'centrepiece' of the adversarial criminal trial was seen to be actually constitutive of the whole of the jurisdiction.

The local court, for instance, despite being convened as a court of adversarial justice, has been said to be less adversarial than inquisitorial. ${ }^{29}$ This is phrased in the context of the triviality of local court justice and the way the formality of adversarial justice may be dispensed with for a more informal approach at the discretion of the magistrate. Local court magistrates do occupy the unique position of arbiters of law and fact, which means that they find themselves in the position of being able to enquire in to the lives of defendants in a way that may not characterise the independence of the adversarial process in the higher courts. This is especially the case given the large number of litigants in person that regularly appear before the local court. With the exception of judge alone trials in the higher courts, local court thus provides a unique tribunal through which members of the community gather in a relatively informal environment, without the processes, procedures and personnel that otherwise characterise the due processes of the higher courts. Importantly, this informality also allows for court intervention and therapy that has since been expended upon in the form of community justice.

28 McBarnet, D. (1981) Conviction: Law, the State and the Construction of Justice, Palgrave Macmillan: UK, pp. 143.

29 See Carlen, P. (1976) 'The Staging of Magistrates' Justice', British Journal of Criminology, 16, 1, 53; McBarnet, D. (1981) 'Magistrates' Courts and the Ideology of Justice', British Journal of Law and Society, 8, 2, 188-195 Duff, P. (2001) 'The Limitations on Trial by Jury', International Review of Penal Law, 72, 1-2, 603-609; McConville, M. (1984) 'Prosecuting Criminal Cases in England and Wales: Reflections on an Inquisitorial Adversary', Liverpool Law Review, 4, 1, $15-32$. 


\section{PROBLEM-SOLVING AND PARTICIPATORY JUSTICE}

Problem-solving justice have its origins in problem-based policing. ${ }^{30}$ Such practices seek to engage community members in the pursuit of crime, by examining patterns of crime within community areas and by utilizing the community as a crime prevention entity and as a site of restoration following an offence. Such perspectives helped give rise to concepts such as community prosecution, community courts, and problem-solving punishments, including the first generation of problem-solving courts, such as drug courts. These courts, generally only available to an accused who enters a guilty plea, sought to keep drug dependant offenders out of gaol by enrolling them into a course of supervised treatment that may also involve a community reparation or service order. Offenders who would otherwise face a custodial sentence would thus be directed out of prison by attending to their drug rehabilitation needs while making amends to the community in which their offending took place. ${ }^{31}$

The last decade has seen the rise of several courts and tribunals created specifically to deal classes of offences, criminals and victims. ${ }^{32}$ The problem-solving courts of the State of New York evidence the movement away from traditional common law courts that seek to deal with all matters criminal within the one adversarial model. ${ }^{33}$ Problem-solving criminal courts now comprise several courts that seek to deal with particular and discrete issues in criminal justice in the New York court hierarchy. These courts include the drug court, mental health court, domestic violence court, sex offences court, youth court, and a community court. Knipps and Berman suggest:

Unlike traditional courts, the drug treatment courts shift the focus of proceedings from adjudicating past facts to changing future behaviorspecifically, to the promotion of defendant sobriety through rigorous judicial monitoring of drug treatment. Treatment court judges play an active role in defendants' recovery process, imposing sanctions when program requirements are violated, dispensing rewards when treatment goals are reached. Because of the reduced emphasis on litigation, many practitioners describe proceedings in these courts as distinctly less adversarial, with the prosecution and defense both working toward the same goal of defendant sobriety. ${ }^{34}$

Significantly, each court demonstrates a departure from the principles of

30 Goldstein, H. (1987) 'Toward Community-Oriented Policing: Potential, Basic Requirements, and Threshold Questions', Crime and Delinquency, 33, 1, 6-30.

31 King, M., Freiberg, A., Batagol, B., and Hyams, R. (2009) Non-Adversarial Justice, The Federation Press: Sydney, pp. 138-139.

32 Ibid, pp. 138-169.

33 Berman, G. and Feinblatt, J. (2005) Good Courts: The Case for Problem-Solving Justice, The New Press: New York; Kaye, JS. (2004) 'Delivering Justice Today: A Problem-Solving Approach', Yale Law and Policy Review, 22, 1, 125-151.

34 Knipps, SK. and Berman, G. (2000) 'New York's Problem-Solving Courts Provide Meaningful Alternatives to Traditional Remedies', New York State Bar Association Journal, 72, 8-10. 
adversarial justice for alternative intervention based planning and welfare support that brings trial participants together in new ways.

\section{THERAPEUTIC JUSTICE AND THE DISMANTLING OF THE ADVERSARIAL}

Alternative courts of therapeutic justice are found throughout the common law world, however, the State of New York has demonstrated a particular drive toward these alternative pathways to justice. What is so significant about these courts is the way they are designed to deal with criminal offending in a way that intentionally departs from the rigidities of the adversarial trial. While not all therapeutic courts deal with liability, such as Drug Courts, which may only deal with supervised placement following a guilty plea, others replace the nominal trial process altogether. Domestic violence and sex offence courts are two such examples. These courts are specialised in that they offer an adversarial alternative to the trial court. The New York domestic violence and sex offences courts are diversionary courts. These courts will deal with all offences of a certain character. These courts are still constituted through an adversarial prosecution process, but are alternative to the extent that offer a process that better suits the specific needs of those persons involved in domestic violence and sexualised offences. These persons include the defendant but also include others excluded form nominal adversarial justice - such as the victim of crime. Knipps and Berman highlight the significance placed on the victim:

For all of their diversity, New York's domestic violence courts all follow a common set of principles that were first developed at the Brooklyn Domestic Violence Court in 1996. Key among them is an emphasis on victim safety. Complainants are linked to an on-site victim advocate, who helps them locate needed services such as shelter and counseling. The advocate also serves as a liaison between the court and victims, assuring that complainants are aware of new court dates, court orders and case outcomes-and that the court knows immediately if any further abuse occurs. ${ }^{35}$

The alternative focus on providing ongoing support to victims can be seen through the rise of sex offence courts. Originally piloted in the counties of Nassau, Westchester and Oswego in 2006, sex offence courts provide for the trial of the offender but also allow for the ongoing support of victims and monitoring of the prisoner following conviction. These courts also take an active role by increasing judicial awareness of the consequences of sexual assault by having specifically trained judges and support personnel. Herman suggests that such courts work closely with local service providers to facilitate victim access to advocacy counselling and other services. ${ }^{36}$ These courts take a victim-centred

35 Ibid, p. 10.

36 Herman, K. (2006) 'Sex Offence Courts: The Next Step in Community Management?', Sexual 
approach, which Herman indicates has proven key to the success of the program. By focussing on the needs of victims throughout their trial, the victim is given a measure of participation, as are ongoing support agencies and advocacy groups, which are invited to participate in the training, planning and operations of the court. $^{37}$

The adversarial criminal trial, at least in terms of the rhetoric of the trial as an exclusive institution of defendant, state, judge and jury, is thus of limited relevance for large numbers of persons accused of an offence. With the advent of problem-solving courts, this number is increasing as fewer defendants and victims are subject to traditional adversarial processes. As the local court statistics and movement towards problem-solving courts indicate, few defendants proceed before a judge and jury in the sense of the adversarial trial noted by Dean $\mathrm{J}$ in Dietrich, above. Rather than confine ourselves to the rhetoric of the primacy of adversarial justice, we must examine the various dynamic ways by which wrongdoers are called to account for their actions as based on the interplay of agency, voice and representation that, arguably, constitutes a more informed view of the dynamics of the criminal trial in modern society. Moving away from the notion that the trial is prescribed allows for the mapping of power relations that would otherwise be diminished or discounted as somehow relevant to the modification of the criminal trial.

\section{COMMUNITY JUSTICE: FOUR EXAMPLES}

The community court provides a venue for 'community prosecution'. Community courts now feature across the common law world, from the United States, Canada, England and Wales to Australia. In the State of New York, community prosecution is based on the notion that although prosecutors ought to respond to particular cases, they continue to have a broader responsibility to public safety, crime prevention, and to develop public confidence in the justice system. Community prosecution requires prosecutors to work differently, and with different people, than is traditionally the case. Prosecutors thus work with residents, victims, community groups and other government agencies. ${ }^{38}$ The main difference involves the accountability of the prosecutor. Rather than report success in terms of cases disposed of, or length of sentence, community prosecutors measure the effect of their work on neighbourhood 'quality of life', community attitudes and crime rates. An example of the movement toward interventionist community justice that departs from the standard adversative criminal trial can be found in the Midtown Community Court of central Manhattan, New

Assault Report, 9, 5, 77.

37 Ibid.

38 Berman, G. and Fox, A. (2001) 'From the Margins to the Mainstream: Community Justice at the Crossroads', Justice System Journal, 22, 2, 205-206. 
York. Launched in 1993, the Midtown Community Court provides fuses service provision with specialty court lists, such that accused and victims may attend the social services clinic, fatherhood and workforce development program, community restitution program, adolescent diversion program, and human trafficking court. ${ }^{39}$

The Downtown Community Court in Vancouver, Canada, opened in 2008 as one of Canada's original community courts. The British Columbia Justice Review Task Force was initially tasked to find solutions for the high degree of recidivist offending and the threat this posed to the community. ${ }^{40}$ Vancouver's Downtown Community Court pioneered an innovative approach that extended justice beyond the participatory model, to combine the services of justice officials, health care providers and social services in one courthouse. Previous experience with offenders in the Vancouver area demonstrated that many had problems with health and social issues, specifically alcoholism, mental illness, addiction to drugs, poverty and homelessness. The remit of the community court is to encourage new relationships between trial participates, under the supervision of the court, this invariably bring partner organisations together in new ways and substantially modifies the role of the processes adopted from adversarial to inquisitorial, court-led, and based in treatment. The court works with community and religious groups, residents, the non-profit sector. The community court brings together traditional trial participants, including the police and prosecution, to determine approaches that may further reduce crime and address the needs of offenders. This means that prosecutors consult with offenders, as well as victims and the broader community.

The English pilot 'Engaging Communities in Criminal Justice' sought to make new connections between key criminal justice stakeholders, within a community context. The Ministry of Justice provides that the scheme be established that had as it object a new way of organising justice around the needs of community stakeholders, including the offenders and victims. ${ }^{41}$ It required a new way of organising the traditional trial participants, the police, prosecution, defence and the court itself. The consultation document Engaging Communities in Criminal Justice follows the Cabinet Office Review 'Engaging Communities in Fighting Crime' by Louise Casey ('the Casey Review'), which determined that:

39 See http://www.courtinnovation.org/project/midtown-community-court. Another leading example is the Red Hook Community Justice Center in Brooklyn, New York, see http://www. courtinnovation.org/project/red-hook-community-justice-center.

40 British Columbia Justice Review Task Force (2005) Beyond the Revolving Door: A New Response to Chronic Offenders, Provence of BC. See http://www2.gov.bc.ca/gov/content/ justice/criminal-justice/vancouver-downtown-community-court.

41 Ministry of Justice (2009) Engaging Communities in Criminal Justice - Green Paper, UK Government. 
It is important that citizens are engaged in ways that are quick, easy and reasonable. The public should not be expected to understand the 'system' police, local authorities and the criminal justice system should be expected to understand the public. In order to achieve this across so many different and disparate organisations, it is reasonable to expect that there are some common and nationally recognisable structures that everyone can understand and use. ${ }^{42}$

Community justice was given form in England and Wales by the establishing of Community Justice Centres, specifically the North Liverpool Community Justice Centre, which featured as the only centre to open. In 2013, it ceased operation and the general power to engage the offender, victim and community in a therapeutic model of inquisitorial and supervised justice was transferred to the Magistrates and Crown Courts, whose powers of intervention and treatment are now available under the amended Powers of Criminal Courts (Sentencing) Act 2000 (UK) and the Criminal Justice Act 2003 (UK). Community justice in England and Wales has now been mainstreamed to the central criminal courts, albeit, the housing of all services in a neighbourhood court complex has been abandoned.

The Powers of Criminal Courts (Sentencing) Act 2000 (UK) and the Criminal Justice Act 2003 (UK) now provide the central criminal courts with powers of therapeutic intervention that allows such courts to depart from their adversarial processes for inquisitorial procedures that combats antisocial behaviour by utilising a range of pre and post-sentencing supervisory arrangements that require the offender to reconnect to the community and victim in order to deter future offences such as vandalism and graffiti, theft, and intoxicated offending.

The Neighbourhood Justice Centre in Melbourne, Australia, requires the court to engage police, prosecutors, offenders and victims in an ongoing dialogue with the community and service providers. The Courts Legislation (Neighbourbood Justice Centre) Act 2006 (Vic) established the Neighbourhood Justice Centre, which commenced operation in 2007. The Neighbourhood Justice Centre comprises a Neighbourhood Justice Court, which sits as a Magistrates' Court with jurisdiction to hear all matters except committals and sexual offences, together with the criminal division of the Children's' Court, the Victorian Civil and Administrative Tribunal, and the Victims of Crime Assistance Tribunal. One magistrate is appointed to the Neighbourhood Justice Court, which is able to exercise the jurisdiction of any of the above courts or tribunals. The Courts Legislation (Neighbourhood Justice Centre) Act 2006 (Vic) amended the Magistrates' Court Act 1989 (Vic) to establish the Neighbourhood Justice Division and provide for a problem-solving court under s $4 \mathrm{M}(5)-(7)$, as follows:

42 Casey, L. (2008) Engaging Communities in Fighting Crime, Crime and Community Review, Prime Ministers Cabinet Office: United Kingdom, p. 78. 
(5) In assigning a magistrate to the Neighbourhood Justice Division, the Chief Magistrate must: (a) have regard to the magistrate's knowledge of, or experience in the application of, the principles of therapeutic jurisprudence and restorative justice; and (b) consult with the President of the Children's Court.

(6) The Neighbourhood Justice Division must exercise its jurisdiction with as little formality and technicality, and with as much expedition, as the requirements of this Act and the Sentencing Act 1991 and the proper consideration of the matters before the Court permit.

(7) The Neighbourhood Justice Division must take steps to ensure that, so far as practicable, any proceeding before it is conducted in a way which it considers will make it comprehensible to the parties to the proceeding.

Service providers are also housed within the Neighbourhood Justice Centre. These services include victims' support, mediation, specialised mental health, drug and alcohol treatment, counselling, housing support, employment and training support, Aboriginal and Torres Strait Islander support services, and the provision of legal advice. Staff at the Neighbourhood Justice Centre are able to help offenders, victims and witnesses locate services relevant to their matter, to prepare for their court appearance, to access support during their appearance as victim or witness, and to connect with corrections officers for the purpose of organising restorative justice interventions where ordered by the court.

The objects of the Neighbourhood Justice Centre set out its problemsolving remit. The Neighbourhood Justice Centre was established to provide a new approach to the old problem of offenders and victim not having access to the services they need in the once place. It also serves to provide a network of support and access to justice that would not otherwise be available. The benefit of this approach is that it forges new connections between stakeholders that provide pathways of communication to bring stakeholders together in new ways. The judiciary, court staff, counsel, corrections, and service providers would normally be housed in different buildings that geographically separate each area. Exacerbating this separation is the tradition of the courts being removed from the executive arm of government that administers and supervises sentences. Service providers would be removed further still, which may not connect to corrections, and most likely not connect to the courts at all.

The housing of each of the arms of the courts, justice administration and service provision in the one place encourages the development of a new approach to justice based on a shared understanding the role of each stakeholder. The development of this knowledge builds bridges between areas of justice that are traditionally separated, providing for the cohesive delivery of justice processes that can affect victim participation and satisfaction, and the recovery of offenders. This development of a knowledge base seeks to assist crime prevention by identifying and linking resources to respond to the causes of crime, by enabling providers to address disadvantage and support the local community. Increasing confidence 
amongst stakeholders by providing direct access to justice is one of the outcomes which also empowers local community members.

\section{ADVERSARIAL JUSTICE RE-DEFINED: MIXED AND HYBRID PROCESSES AND THE DOMESTIC LAW OF COMMON LAW STATES}

In $R v$ Cook [1997] 1 SCR 1113, the Supreme Court of Canada considered the extent to which the Crown ought to be required to call a witness. The court ruled that the duty to call prosecution witnesses ought to be left to the Crown as a matter of discretion, save in exceptional circumstances. Where the trial judge thinks a witness ought to be called then they possess the power to do so. The prosecution is not compelled to call any particular witness, including the victim of the offence. The prosecution's ability to 'ambush' the defence with a surprise case is limited by its duty to disclose the prosecution case to the defence. It is thus for the defence to call a witness where not previously called by the prosecution. The trial judge would only call a witness on his or her own motion in extraordinary circumstances, such as if there a 'gap' is left in the prosecution case or where a witness's testimony may give the defendant a real change of acquittal. With regard to the exercise of that discretion, L'Heureux Dubé J makes the following remarks on the adversarial process (at par 39):

The adversarial process functions on the premise that it is the obligation of the Crown to establish a case beyond a reasonable doubt against the accused. Once this threshold has been surpassed, however, it is up to the accused to call evidence or face conviction: R. v. Noble, 1997 CanLII 388 (S.C.C.), [1997] 1 S.C.R. 874. The adversarial nature of the trial process has been recognized as a principle of fundamental justice (R. v. Swain, 1991 CanLII 104 (S.C.C.), [1991] 1 S.C.R. 933). As such it should be construed in a way that strikes a fair balance between the interests of the accused and those of society: $R$. $v$. Levogiannis, 1993 CanLII 47 (S.C.C.), [1993] 4 S.C.R. 475; Cunningham v. Canada, 1993 CanLII 139 (S.C.C.), [1993] 2 S.C.R. 143, at p. 148; Re B.C. Motor Vehicle Act, 1985 CanLII 81 (S.C.C.), [1985] 2 S.C.R. 486. In my view, placing an obligation upon the Crown to call all witnesses with information bearing on the case would disrupt the inherent balance of our adversary system. I note, however, that the accused is also not obliged to call the witness. As I propose to expand upon, there are other options which are available to the accused in an appropriate case including, but not limited to, asking the trial judge to call the witness, commenting in closing on the witness' absence, or asking the trial judge to comment.

The notion that the criminal trial is constituted through the interplay of various discourses as to accusation and participation that traverse the adversarial and inquisitorial approaches to justice is controversial. Central to this context is the extent to which these discourses may be constituted as a more truthful or authoritative account of how the trial should be constituted. The scope, function, 
procedures and rules by which the institutional presence of the trial is constructed is thus largely determined by the discourses that are entertained as significant and determinative. The cases of $R v$ Camberwell Green Youth Court [2005] 1 All ER 999, Gately $v$ The Queen (2007) 232 CLR 208, and Crawford $v$ Washington (2004) 541 US 36 show how discourses of adversarial justice may be broad enough to contemplate alternative ways of doing justice, including court-led prosecution and the modification of evidence to allow for out of court proceedings to protect vulnerable witnesses from aggressive modes of examination.

These differences notwithstanding, perspectives emerge that suggest that the criminal trial is 'under attack' due to the introduction of victim rights, the pursuit of local and national security, the decline of the contested trial, and out of a general critique of the values of adversarialism, that is, the trial is under a normative attack by those seeking a different kind of trial experience such as one that seeks to include the aims of reconciliation and restoration. ${ }^{43}$ However, as indicated in $R v$ Cook, the adversarial process, in so far as it defines the modern criminal trial, is not as ridged as one may think. The decline of the contested trial and the influence of the politics of national and domestic security, law and order, and victim rights, may well challenge aspects of the criminal process, but it is arguable whether any of these fronts do anything to the trial that history and discourse does not already provide. This is because the model of adversarial justice that is emerging into the twenty-first century could already be found in the various (and competing) discourses of justice that have shaped the trial over the last century or more.

In $R v$ Cook, the Supreme Court of Canada indicates the outer limits of the adversarial process. These limits help the court establish the ambit of the prosecution's discretion to call witnesses, including the victim or complainant. However, the adversarial process that the Supreme Court of Canada defends in $R$ $v$ Cook is neither prescriptive nor exclusive. The court holds open the possibility that a trial judge may intervene beyond any motion put by the litigants. However, L'Heureux Dubé J makes clear the fact that the trial judge may still exercise that discretion where a witnesses' testimony is materially relevant to the indictment or where it is necessary to call a witness in the interests of justice, to prevent an unjust conviction. The adversarial process thus endorsed by the Supreme Court of Canada does not limit the processes used by a court so long as judicial oversight is guided by trial fairness and due process. Much like the inquisitorial courts of continental Europe, judicial intervention comes to be identified as a significant aspect of the adversarial tradition. As Jago $v$ District Court of NSW (1989) 168 CLR 23 reminds us, once the case is brought before a court it is for

43 Duff, A., Lindsay, F., Marshall, S., and Tadros, V. (2007) The Trial on Trial Volume 3: Towards a Normative Theory of the Criminal Trial, Hart Publishing: Oxford., p. 1-10. 
the judge to exercise a measure of judicial oversight to ensure that a fair trial ensues. This means that despite the tenets of adversarial justice that limit each party in a procedural and substantive way to ensure that a contested version of the facts emerge, the court is still able to exercise a measure of supervision restoring the scope of the trial beyond adversative exchange. This point is significant as challenges the assumption that the adversarial trial is opposed to, or incompatible with, inquisitorial or judicially supervised and led approaches. Inquisitorial approaches allow the court to go beyond its independent role to call witnesses of its own motion. Counsel in such jurisdictions will assist the court rather than contest a version of evidence as adduced by the opposing party. Issues raised in $R v$ Cook would thus be familiar to an inquisitorial court of criminal justice in its reliance on the supervisory capacity of the trial judge.

The significance of discourse to the development of systems of procedural justice is discussed in terms of the development of the 'accusatorial trinity'; the role of prosecution, defence and judge. ${ }^{44}$ This 'trinity' allows for points of connection between the two systems of justice that provide for the movement of ideas and approaches that may be rooted to the structural framework of the legal system of each state. Summers argues that this 'accusatorial trinity', and the balancing of interests therein, became the accepted basis upon which the jurisprudence of the ECtHR is considered as successfully mapping a coherent notion of the 'fair trial' as one based on participatory justice. ${ }^{45}$ This cohesion is mete out through the adversarial procedural requirement and doctrine of equality of arms that has emerged in the ECtHR's jurisprudence. ${ }^{46}$ However, the process as it applies to criminal proceedings is defined in terms of a 'balancing' of rights and is not exacting. This approach appears to focus on the fundamental characteristics common to each jurisdiction mixed and hybrid adversarial/inquisitorial systems, as Summers explains:

Although inconsistencies in the Court's notion of fairness are particularly evident in relation to the case law on the right to question witnesses, they are also reflected in the failure to address serious institutional flaws in various European criminal procedural systems. There can be little doubt that the coherence and consistency of procedural fairness could be improved through an acknowledgement of the reliance of its adversarial proceedings and equality of arms doctrines on the accusatorial trinity. A more sound approach to the regulation of fairness in European criminal trials requires recognition both of the European procedural tradition and the common institutional values which it implies. ${ }^{47}$

44 Summers, S. (2007) Fair Trials: The European Procedural Tradition and the European Court of Human Rights, Hart Publishing: Oxford., p. 27.

45 Ibid. pp. 99-103.

46 See Doorson $v$ The Netherlands (1996) 22 EHRR 330.

47 Summers, S. (2007) Fair Trials: The European Procedural Tradition and the European Court of Human Rights, Hart Publishing: Oxford., p. 180. 
It is worth noting however that there are dissimilarities between the adversarial and inquisitorial traditions that do not appear to be directly compatible, as Hodgson notes:

To the common lawyer, this direct judicial questioning of the accused may seem overbearing. In England and Wales, the defendant is protected from such interrogation and is not questioned directly unless she chooses to take the stand to give evidence. However, questioning of the accused in an adversarial process is very different from judicial questioning in France. It is not conducted by a neutral party, designed to clarify matters or to give the accused the opportunity to explain herself, but rather, by a partisan player whose concern is not with the truth, but with the construction of a case that undercuts that of the accused. However, it is important to remember that the judge's questioning of the accused in France is based upon the case dossier. ${ }^{48}$

European civil law processes therefore place a different focus on the accused and their requirement to directly participate in proceedings. The 'right to silence' in the common law tradition, or at least the right to put the prosecution case to proof unless displaced by statutory modification, may be a significant point of departure between inquisitorial and common law systems. On the other hand, this apparent disconnect may not be borne out in practice, given that in most instances matters will be disposed of in the lower courts constituted by a summary process where judicial intervention and often guidance of parties is common. In inquisitorial and adversarial courts, participation of the accused will occur with significant oversight by the court and defence counsel. This point is more relevant where litigants appear in person, as a substantial number do in the lower courts of summary justice. There may, however, be points of significant departure around notions of 'truth' as they are constructed from the facts in evidence or case dossier in each tradition. Hodgson suggests this in terms of the fundamental differences between agreed function of prosecution, defence and state:

Whilst the functions of prosecution, defence and trial exist in both jurisdictions, the ways in which these tasks are defined and understood by, and distributed between legal actors is not the same in inquisitorial and adversarial procedure. Much depends upon the relationship between trial and pre-trial, the nature of the 'truth' that is sought through the process of investigation and trial, and who is responsible for the establishment of that 'truth'. ${ }^{49}$

We must, however, proceeds carefully before we dismiss as incompatible the processes of adversarial and inquisitorial justice. The European civil law tradition given renewed form in the human rights frameworks of the EU and ECHR and the jurisprudence that follows indicates how inquisitorial and

48 Hodgson, J. (2006) 'Conceptions of the Trial in Inquisitorial and Adversarial Procedure', in Duff, A., Farmer, L., Marshall, S. and Tadros, V. (eds.) The Trial on Trial Volume 2: Judgement and Calling to Account, Hart Publishing: Oxford, p. 238.

49 Ibid,. p. 241. 
adversarial process may present consistently in terms of a common trial process, where a focus on participatory justice takes us beyond procedural limitations to examine the relationships between trial stakeholders and the 'accusatorial trinity'. This European tradition challenges certain assumptions that may be plainly arguable as a matter of national rhetoric, but not seen in actual practice. Community justice for instance challenges the normative assumption that 'truth' is judge focused in one jurisdiction, and counsel-led in another. For those reasons, summary, therapeutic and community-based justice breaks so many of the rules that constitute the adversarial process yet advances the interests of justice by making available a mode of justice delivery that meets the needs of a range of trial participants, ordinarily excluded from adversative approaches. The continued momentum of law reform in common law jurisdictions will therefore be toward the critical evaluation of the exclusivity of the adversarial trial for the integration of alternative, inquisitorial procedures that afford equality of arms within a participatory model of accessible justice. 